\title{
Production of transgenic goat (Capra hircus) with human Granulocyte Colony Stimulating Factor (hG-CSF) gene in Brazil
}

\author{
VICENTE J.F. FREITAS ${ }^{1}$, IRINA A. SEROVA ${ }^{2,5}$, LYUDMILA E. ANDREEVA ${ }^{3}$, \\ GUENNADI A. DVORYANCHIKOV ${ }^{4}$, EDILSON S. LOPES-Jr. ${ }^{1}$, DÁRCIO I.A. TEIXEIRA ${ }^{1}$, \\ LUCIENE P.B. DIAS ${ }^{5}$, SUELY R.G. AVELAR ${ }^{1}$, RAYLENE R. MOURA ${ }^{1}$, LUCIANA M. MELO ${ }^{1}$, \\ ALEXSANDRA F. PEREIRA ${ }^{1}$, JOÃO B. CAJAZEIRAS ${ }^{1}$, MARIA L.L. ANDRADE ${ }^{1}$, \\ KARLLIELY C. ALMEIDA ${ }^{1}$, FRANCISCO C. SOUSA ${ }^{1}$, ANTONIO C.C. CARVALHO \\ and OLEG L. SEROV ${ }^{2}$ \\ ${ }^{1}$ Universidade Estadual do Ceará, Laboratório de Fisiologia e Controle da Reprodução \\ Av. Paranjana 1700, 60740-000 Fortaleza, CE, Brasil \\ ${ }^{2}$ Institute of Cytology and Genetics, Russian Academy of Sciences, Lavrentev av. 10, 630090 Novosibirsk, Russia \\ ${ }^{3}$ Institute of Molecular Genetics, Russian Academy of Sciences, Kurchatov sq. 2, 123182 Moscow, Russia \\ ${ }^{4}$ School of Medicine, University of Miami, Miami, Florida 33124, USA \\ ${ }^{5}$ Universidade Federal do Rio de Janeiro, Instituto de Biofísica Carlos Chagas Filho, CCS Bloco G, \\ Ilha do Fundão, 21949-900 Rio de Janeiro, RJ, Brasil \\ Manuscript received on December 1, 2006; accepted for publication on September 25, 2007; \\ contributed by ANTONIO C.C. CARVALHO*
}

\begin{abstract}
In order to produce transgenic goats with hG-CSF, a total of 24 adult Saanen and 48 adult undefined breed goats were used as donors and recipients, respectively. Donors were estrus-synchronized with vaginal sponges and superovulated by a treatment with $200 \mathrm{mg}$ FSH given twice daily in decreasing doses over 3 days starting $48 \mathrm{~h}$ before sponge removal. Ovulation was induced by injecting $100 \mu \mathrm{g}$ GnRH $36 \mathrm{~h}$ after sponge removal. The recipients also received an estrus synchronization treatment. Donors were mated with fertile Saanen bucks and, approximately $72 \mathrm{~h}$ after sponge removal, zygotes were recovered surgically by flushing oviducts. The recovered zygotes were briefly centrifuged to a reliable visualization of the pronuclei. The DNA construct containing hG-CSF gene flanked by goat and bovine $\alpha$ s1-casein sequences was injected into pronuclei of 129 zygotes. The microinjected embryos (3-6 per female) were transferred to 27 recipients. Ten recipients became pregnant and 12 kids were born. One transgenic male founder was identified in the group of kids. This is the first report of a birth of a transgenic goat in Latin America.
\end{abstract}

Key words: transgenesis, goat, hG-CSF, DNA microinjection, embryo.

\section{INTRODUCTION}

Production of valuable proteins of pharmaceutical interest in the milk of transgenic farm animals has become an attractive alternative to microbial and animal cell bioreactors. The generation of transgenic large ruminants (cattle) is, however, very expensive because of the long gestation period, small litter size and high maintenance

\footnotetext{
*Member Academia Brasileira de Ciências Correspondence to: Vicente José de F. Freitas E-mail: vjff@pq.cnpq.br
}

costs of this ruminant livestock species. Contrarily, dairy goats are less expensive, have shorter generation times and produce multiple offspring. For these reasons, the use of dairy goats as a bioreactor animal is of interest. There have been several reports on the production of transgenic goats (Ebert et al. 1991, Ebert and Schindler 1993, Gootwine et al. 1997) and the feasibility of the large-scale production for the industrial application has been confirmed (Baldassarre et al. 2003, Baldassarre and Karatzas 2004). 
The human Granulocyte Colony Stimulating Factor (hG-CSF) is a hematopoietic growth factor that stimulates the proliferation and the differentiation commitment of neutrophil precursor cells, and enhances some of the functional properties of mature neutrophils (Morstyn and Burgess 1988). Following its production as a recombinant human protein (Souza et al. 1986), hG-CSF has been the most widely used hematopoietic growth factor due to its proven efficacy against different forms of neutropenia and chemotherapy induced leucopenia. Furthermore, hG-CSF stimulates the mobilization of progenitor cells for autologous or allogenic transplantation (Anderson et al. 2006, Viret et al. 2006). The hG-CSF has been cited for use in treatment of other human health problems, such as myocardial infarction (Oh et al. 2006) and cerebral ischaemia ( $\mathrm{Lu}$ and Xiao 2006). In addition, Ko et al. (2000) have developed a transgenic female goat harboring goat-casein promoter/hG-CSF fusion gene by microinjection into fertilized one-cell goat zygotes.

Following a feasibility study in which transgenic mice that secrete high levels of hG-CSF into their milk were produced (Dvoryanchikov et al. 2005) at the Institute of Biophysics Carlos Chagas Filho (Universidade Federal do Rio de Janeiro, Brazil), we initiated a project to produce hG-CSF-transgenic goats in Brazil. Thus, the aim of this study was to examine the overall efficiency of production of goats that are transgenic for the hG-CSF. This study resulted in the production of a transgenic goat containing a goat s1-casein/human G-CSF fusion gene, the first transgenic goat produced in Latin America.

\section{MATERIALS AND METHODS}

CONSTRUCtion OF G-CSF EXPRESSION Vector

The hG-CSF gene was fused to both goat and bovine DNA sequences of s1-casein gene (CSN1S1). The DNA construct was inserted into a plasmid vector, named pGCm3 (Fig. 1). This expression vector was designed based on pGCm1 and pGCm2 previously described and used for production of transgenic mouse (Dvoryanchikov et al. 2005). The pGCm3 DNA insert (6429 bp) has a 5 'flanking fragment (3387 bp) originated from goat CSN1S1 gene (Ramunno et al. 2004). This fragment includes a promoter region, the first exon, the first intron and the $12 \mathrm{bp}$ from second exon. In pGCm 3 construct, there is the full-length hG-CSF gene (1504 bp) followed by 3 'flanking fragment (1538 bp) originated from bovine CSN1S1 gene. The last sequence includes the exon 18 , the intron 18 , the exon 19 and a 3'-untranslated region (3'UTR).

\section{DNA PREPARATION FOR ZYGOTE MicroinJeCtion}

The DNA insert was cut out from pGCm3 using SalI digestion. After fractionating the digests in $0.7 \%$ agarose gel, a $6431 \mathrm{bp}$ fragment was isolated. The fragment was eluted from agarose gel using Qiagen ${ }^{\circledR}$ columns according to recommendations of the manufacturer. For injections, DNA was diluted in $0.01 \mathrm{M}$ Tris- $\mathrm{HCl}$ with 0.25 mM EDTA, at pH 7.4.

\section{EXPERIMENTAL ANIMALS AND ETHICS}

A total of 23 adult Saanen goats (1-5 years old) were used as embryo donors in this study, while 48 undefined breed goats (2-5 years old) served as recipients for the microinjected embryos. The study was carried out between mid-January and mid-February 2006. Studies were conducted in conformance with guidelines of animal care. This project was approved by the Animal Ethics Committee of the State University of Ceará (CEUA/UECE) as well as the Biosecurity National Technical Committee (CTNBio).

\section{ESTRUS SYNCHRONIZATION AND SUPEROVULATION}

The timing of estrus was synchronized in donors and recipients with intravaginal sponges (Progespon, Syntex, Buenos Aires, Argentina) containing $60 \mathrm{mg}$ medroxyprogesterone acetate for 10 days and an injection of $75 \mu \mathrm{g}$ cloprostenol (Prolise, Arsa, Buenos Aires, Argentina) on the morning of the eighth day. Donors received a total equivalent to $200 \mathrm{mg}$ NIH-FSH-P1 (Folltropin-V, Vetrepharm, Ontario, Canada) given twice daily in decreasing doses over 3 days (50/50, 25/25 and 25/25 mg) starting $48 \mathrm{~h}$ prior to sponge removal. Also $48 \mathrm{~h}$ prior to the end of progestagen treatment, recipients were injected with 300 IU eCG (Novormon, Syntex, Buenos Aires, Argentina). Thirty-six hours after sponge removal, donors received $100 \mathrm{mg}$ GnRH (Fertagyl, Intervet, Boxmeer, Holanda). Donors were hand bred at 36 and $48 \mathrm{~h}$ after sponge removal using Saanen bucks of known fertility. 


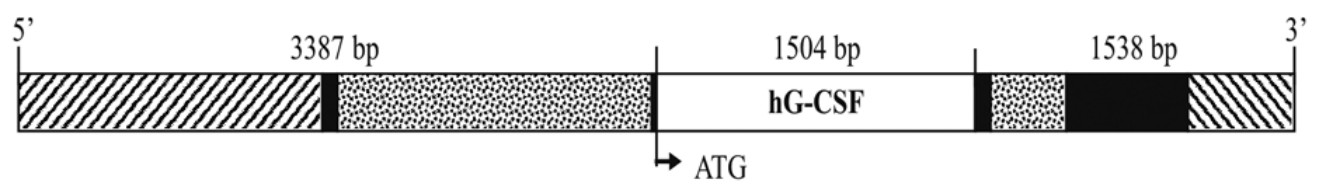

\author{
5'-UTR region of goat $\alpha$ s1-casein gene \\ Exons 1,2 (12 bp), 18 and 19 of $\alpha$ s1-casein gene \\ Introns 1 and 18 of $\alpha$ s1-casein gene \\ Genomic sequence of hG-CSF \\ 3'-UTR region of bovine $\alpha$ s1-casein gene
}

Fig. 1 - Construction pGCm3 with hG-CSF under control of 5'-flanking sequence of goat $\alpha$ s 1-casein gene used to microinjection into goat zygotes.

\section{EMBRYO RECOVERY}

Donors and recipients were deprived of food and water for $24 \mathrm{~h}$ prior embryo recovery and transfer. Embryos were surgically recovered $72 \mathrm{~h}$ following sponge removal. A low dose $(0.1 \mathrm{mg} / \mathrm{kg})$ of xylazine hydrochloride (Rompun, Bayer, São Paulo, Brazil) was intramuscularly injected as a preanesthetic agent. After a peridural injection $(7 \mathrm{mg} / \mathrm{kg}$ ) of lidocaine (Anestésico L, Eurofarma, São Paulo, Brazil) a mid-ventral incision was made and the reproductive tract was exteriorized. Ovaries were observed for fresh ovulation sites to serve as an estimate of the number of embryos expected. The oviduct was then flushed retrogradely with $10-15 \mathrm{ml}$ of sterile phosphate-buffered saline. The flushing medium was collected into sterile Petri dishes and examined under a stereomicroscope (Nikon SMZ-800, Kawasaki, Japan) for the presence of ova/embryos.

\section{EMBRYO MANIPULATION AND MICROINJECTION}

The microinjection was carried out using only fertilized one-cell embryos. In order to visualize pronuclei all zygotes were briefly centrifuged at $13,400 \mathrm{rpm}$ for 4 6 min. After centrifugation, if the pronuclei were not visible, they were placed in droplets of M-2 medium supplemented with $10 \%$ FCS and covered with mineral oil, and briefly cultured at $37^{\circ} \mathrm{C}$ with $5 \% \mathrm{CO}_{2}$. The zygotes with visible pronuclei were placed in droplets of M-16 medium supplemented with $10 \%$ FCS prior to microinjection, which was performed under inverted microscope with DIC optics (Nikon TE2000, Kawasaki, Japan) and a pair of micromanipulators (Narishige, Tokio, Japan). The DNA fragment isolated from a plasmid containing the pGCm3 gene was injected into the one of two pronuclei in volume of 1-2 pl. Noticeable swelling of the nuclei was the criterion for successful microinjection. Microinjected embryos were cultured for $1-2 \mathrm{~h}$ at $37^{\circ} \mathrm{C}$ with $5 \% \mathrm{CO}_{2}$ to evaluate post injection survival. The surviving zygotes were maintained in culture until embryo transfer. Non-injected zygotes with invisible pronuclei were further cultured to confirm fertilization by cleavage.

\section{Embryo Transfer and Pregnancy Diagnosis}

Successfully microinjected embryos were transferred into the oviduct of estrus-synchronized recipient goats following laparoscopic exploration in order to confirm the presence of at least one recent ovulation. For embryo transfer, a mid-ventral laparotomy was established and the reproductive tract was exteriorized. A Tomcat catheter containing the embryos was introduced through the fimbria $2-3 \mathrm{~cm}$ into the oviduct and the embryos were injected into the lumen. Three to six embryos were transferred per recipient. Pregnancy was detected by ultrasound at 28-35 days following transfer, using a Falco 100 scanner (Piemedical, Maastricht, The Netherlands) equipped with a transrectal 6-8 $\mathrm{MHz}$ linear array. 


\section{IDENTIFICATION OF TRANSGENIC GOATS}

DNA was extracted from skin biopsies taken from the ears of 2-week-old kids. After proteinase-K/SDS treatment, a phenol-chloroform extraction was performed following the protocol of Sambrook et al. (1989). The identification of transgenic animals was carried out by PCR amplification using the following pairs of primers: $\operatorname{PrA} / \operatorname{PrB}$ and $\operatorname{PrC} / \operatorname{PrD}$, originating products of $700 \mathrm{bp}$ and $530 \mathrm{bp}$, respectively (Table I). The reaction control was made with a pair of primers designed to $5^{6}$-flanked sequence of goat $\alpha$ s 1-casein gene (496 bp PCR product). The PCR was performed using $1 \mu \mathrm{g}$ of genomic DNA, $1 \mu \mathrm{M}$ of each primer and $0.5 \mathrm{U}$ of Taq polymerase to a total volume of $25 \mu \mathrm{L}$. The amplification was conducted under following conditions: denaturing for 3 minutes at $95^{\circ} \mathrm{C}$, then 35 cycles $\left(30 \mathrm{~s}\right.$ at $95^{\circ} \mathrm{C}, 30 \mathrm{~s}$ at $55^{\circ} \mathrm{C}$ and $30 \mathrm{~s}$ at $72^{\circ} \mathrm{C}$ ) and the final stage for $5 \mathrm{~min}$ at $72^{\circ} \mathrm{C}$. The PCR products were analyzed by electrophoresis in a 1.5 or $3 \%$ agarose gel and visualized by ethidium bromide staining.

\section{STATISTICAL ANALYSis}

Data were expressed as mean \pm SEM. Differences between means were based on $t$-test. Probability of $<0.05$ was considered to be significant statistically.

\section{RESULTS AND DISCUSSION}

The response to superovulation and the results of embryo recovery and evaluations are presented in Table II. All donors showed estrus and were responsive to the superovulation treatment ( $\geq 5$ ovulations/female). The superovulation response and the embryo recovery rate from donors found in the present study were superior when compared to those reported in previous studies (Gootwine et al. 1997, Lee et al. 2000, Freitas et al. 2003).

Altogether 379 oocytes/embryos were recovered, of which $75.5 \%$ were fertilized and most were at the one-cell stage. These results can be explained by the effect of GnRH injection on the synchronization of ovulation. This way, the donors were hand mated at the good time in order to guarantee a high fertilization rate. In addition, the use of GnRH following sponge removal influenced the stage of development of embryos recovered, a key parameter for the success of a transgenic founder generation program (Baldassarre et al. 2004).
The same authors, working with BELE goats and the FSH-GnRH protocol obtained almost $80 \%$ fertilized oocytes of which the most of them were at the pronuclear stage of development. It has been previously suggested that successful integration of foreign DNA is more likely following microinjection of pronuclear-stage embryos than when performed in two-cell stage embryos (reviewed by Baldassarre and Karatzas 2004).

Our results showed the efficiency of oviduct recovery to obtain a high number of microinjectable embryos (79.5\%, Table II). However, the surgical nature of this technique limits the number of procedures performed on the same donor before surgical adhesions render the animal unusable for further embryo recoveries. A further refinement of the pronuclear microinjection technology has been reported in using in vitro produced zygotes from oocytes recovered by laparoscopic ovum pick-up (Wang et al. 2002).

In our experiment, as mentioned above, the microinjectable one-cell embryos were a significant proportion of the recovered oocytes/embryos (Fig. 2A,B). However, previous results had showed that the zygote cytoplasm of Korean native strain (Lee et al. 2000) and BELE (Baldassarre et al. 2004) goats contains numerous lipid and opaque inclusions. The same was observed in this study with Saanen goats. This feature makes difficult the pronuclei visualization before microinjection of recombinant DNA. In order to improve the pronuclei visualization, zygotes were briefly centrifuged as described earlier (Lee et al. 1997). The procedure allowed us to visualize the pronuclei in some zygotes (Fig. 2C,D) so that total number of goat zygotes with visible pronuclei was $55 \%$ (77 out of 129 ). In the remaining zygotes we were unable to observe a detailed morphology of the pronuclei and the microinjections were done in an area where the pronuclei were most probably located. In these cases, it was impossible to control the efficiency of injection by observing such as an important change in pronucleus morphology as its swelling (Fig. 2D).

Analysis of the pronucleus formation in zygotes of Saanen goats revealed that it was impossible to localize the pronuclei at the early stages of zygote development due to its very small size. After a short-time culture the pronuclei became larger and were clearly visible at about one half of cultured zygotes. The pronuclei 

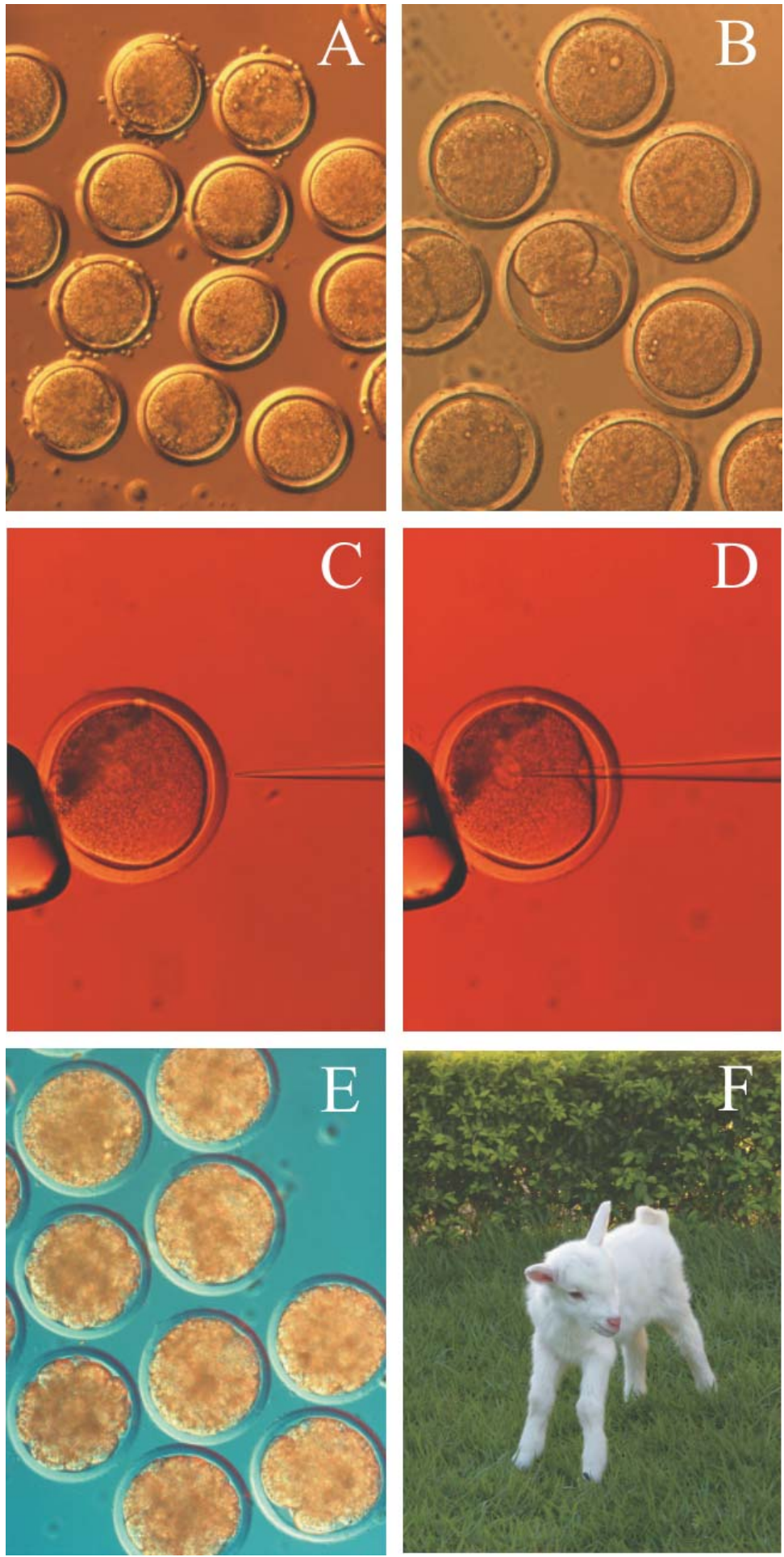

Fig. 2 - Goat embryos at one- and two-cell stage $(\mathrm{A}, \times 150$ and $\mathrm{B}, \times 200)$ obtained from two donors. A goat zygote after centrifugation with two visible pronuclei $(C)$ and the same zygote during microinjection $(\mathrm{D}, \times 300)$. Goat embryos at morula stage after in vitro culture for $96 \mathrm{~h}$ (E, $\times 200)$. "Carlos": a two-week transgenic goat bearing the pGCm3 transgene $(\mathrm{F})$. 
TABLE I

Primers used to identification of transgenic goats.

\begin{tabular}{c|c|c}
\hline Name & Nucleotide sequence & Position $^{\mathrm{c}}$ \\
\hline PrA $^{\mathrm{a}}$ & 5'-AAAGGATAAGGCTAATGAGG-3' & 4543 \\
\hline PrB $^{\mathrm{b}}$ & 5'-CGTTGTACTTTTGTACTGAGC-3' & 5247 \\
\hline PrC $^{\mathrm{a}}$ & 5'-TCTGCAAAAGCAGGCTAAAGC-3' & 3188 \\
\hline PrD $^{\mathrm{b}}$ & 5'-GCCAAGACACTCACCCATCAG-3' & 3718 \\
\hline
\end{tabular}

$\mathrm{a}=$ forward primer, ${ }^{\mathrm{b}}=$ reverse primer, ${ }^{\mathrm{c}}=$ relative to $\mathrm{pCGm} 3$ construct

TABLE II

Time of estrus, number of ovulations, embryo recovery and fertilized oocytes in Saanen goats used as zygote donors.

\begin{tabular}{l|c}
\hline \multicolumn{1}{c|}{ Parameter } & Values \\
\hline Number of treated donors & 23 \\
\hline Interval sponge removal to onset of estrus (h) & $27.0 \pm 2.2$ \\
\hline Number of ovulations & $20.4 \pm 7.3$ \\
\hline Embryo recovery rate (\%) & 79.5 \\
\hline Fertilized oocytes $(\%)$ & 75.5 \\
\hline
\end{tabular}

TABLE III

Estimation of some factors on pregnancy rate of recipient goats after surgically transfer of the microinjected zygotes.

\begin{tabular}{l|c|c}
\hline \multirow{2}{*}{ Parameter } & \multicolumn{2}{c}{ Recipients } \\
\cline { 2 - 3 } & Pregnant & Non Pregnant \\
\hline Time of zygote culture before transfer (hours) & $6.1 \pm 0.6$ & $6.2 \pm 0.3$ \\
\hline Number of transferred zygotes & $4.8 \pm 0.4$ & $4.8 \pm 0.4$ \\
\hline Number of ovulations in recipients at time of transfer & $3.1 \pm 0.4^{\mathrm{a}}$ & $1.9 \pm 0.3^{\mathrm{b}}$ \\
\hline
\end{tabular}

$\mathrm{a}, \mathrm{b}=\mathrm{P}<0.01$

were located near the zygote center emerging from the lipid granules, which were shifted to the zygote poles by centrifuging (Fig. 2C). This stage apparently proceeds shortly the moment of the fusion of male and female pronuclei, and therefore corresponds to the late stages of zygote development. After $96 \mathrm{~h}$ of culture, non microinjected goat embryos developed normally until morula stage (Fig. 2E).

The hormonal treatment used for estrus synchronization was effective to induce estrus in $87.5 \%$ of goat recipients. The estrus began at $26.0 \pm 1.6 \mathrm{~h}$ after sponge removal and the ovulation rate was $1.3 \pm 0.2$. These results were similar to other studies performed in goats (Freitas et al. 1997).
Twenty-seven recipients received the microinjected embryos. The pregnancy rate in this report $(37.0 \%)$ was comparable to previous reports (Gootwine et al. 1997, Lee et al. 2000). In our study, it was observed that the number of ovulations influenced the number of pregnant goats (Table III). It was probably due to an elevated plasma progesterone concentration, provided by a high number of corpora lutea, during early pregnancy that could improve embryonic survival and growth (Pope et al. 1995). Altogether 10 recipients were pregnant and produced 12 offspring. PCR analysis (Fig. 3) finally identified one transgenic goat in this study.

Efficient production of transgenic goats is one of the key factors in applying this technology to the produc- 

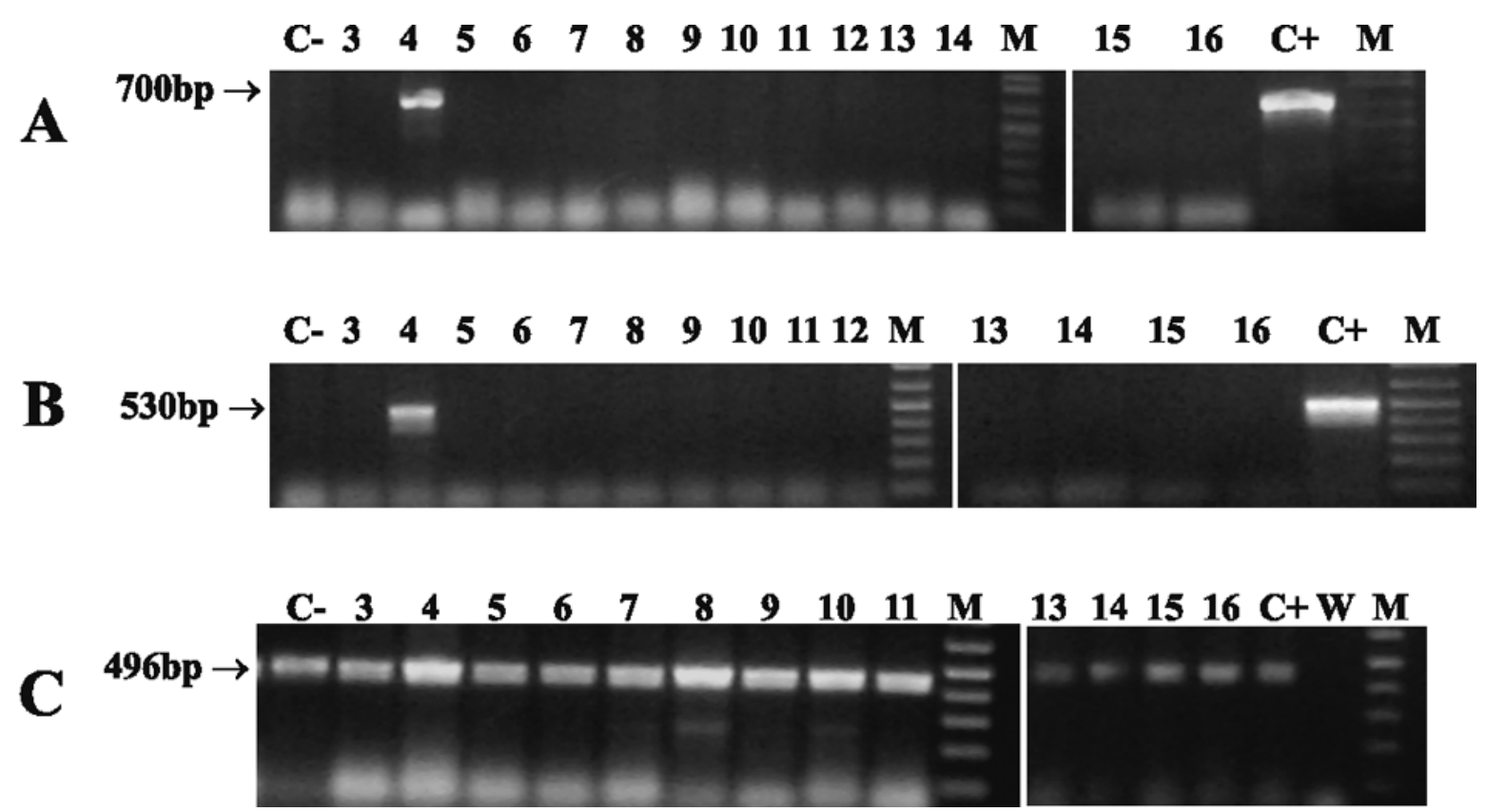

Fig. 3 - Identification of transgenic goat using PCR analysis with $\operatorname{PrA} / \operatorname{PrB}(\mathrm{A})$ and $\operatorname{PrC} / \operatorname{PrD}(\mathrm{B})$ primers. Control amplifications with specific primers designed to 5 -flanking sequence of the goat $\alpha$ s-casein gene (C). C- = negative control, genomic DNA of wild-type goat; 3 to $16=$ DNA sample of experimental goats ( $4=$ "Carlos" positive for the $\mathrm{pGCm} 3$ transgene); $\mathrm{C}+=$ a positive control (mixture of non-transgenic goat genomic DNA and the recombinant $\mathrm{pGCm} 3 \mathrm{DNA}) ; \mathrm{W}=$ no template; $\mathrm{M}=\mathrm{a} 100$ bp ladder.

tion of human pharmaceuticals or other valuable proteins. Our results show that obtaining a reasonable rate of kidding following transfer of microinjected embryos is possible by using the in vivo embryo production and transfer to recipients with a high number of ovulations. In the present study one transgenic kid was produced (Fig. 2F). This transgenic goat represents $8.3 \%$ of the kids born and $0.7 \%$ of the embryos microinjected and transferred. At our knowledge, this is the first report of birth of transgenic goat in Latin America.

\section{ACKNOWLEDGMENTS}

This work was supported by grants from Ministério de Ciência e Tecnologia/Rede Nordeste de Biotecnologia/ Banco do Nordeste (MCT/Renorbio/BNB), Conselho Nacional de Desenvolvimento Científico e Tecnológico/ Programa de Apoio ao Desenvolvimento Científico e Tecnológico (CNPq/PADCT) and by the Program of the Russian Academy of Sciences "Dynamics of plant, animal and human gene polls" (Russia). V.J.F. Freitas and A.C.C. Carvalho are senior investigators of $\mathrm{CNPq}$ (Brazil).

\section{RESUMO}

A fim de produzir caprinos transgênicos para o hG-CSF, utilizou-se 24 cabras Saanen adultas e 48 cabras sem raça definida adultas como doadoras e receptoras, respectivamente. As doadoras tiveram o estro sincronizado por esponjas vaginais e foram superovuladas com $200 \mathrm{mg}$ de FSH em doses decrescentes, duas vezes ao dia e iniciando $48 \mathrm{~h}$ antes da retirada da esponja. A ovulação foi induzida pela injeção de $100 \mu \mathrm{g}$ de $\mathrm{GnRH}$ às $36 \mathrm{~h}$ após a retirada da esponja. As receptoras também receberam um tratamento de sincronização do estro. As doadoras foram cobertas por bodes Saanen férteis e, aproximadamente $72 \mathrm{~h}$ após a retirada da esponja, os zigotos foram colhidos cirurgicamente por lavagem dos ovidutos. Os zigotos colhidos foram rapidamente centrifugados para uma melhor visualização dos pró-núcleos. A construção de DNA, contendo o gene do hG-CSF flanqueado pelos genes caprino e bovino da $\alpha$ s1-caseína, foi injetada em 129 embriões. Os embriões microinjetados ( 3 a 6 por receptora) foram transferidos para 27 receptoras que responderam ao tratamento. Dez receptoras ficaram gestantes e 12 crias foram produzidas. Um macho transgênico fundador foi identificado no grupo de crias 
nascidas. Este é o primeiro relato do nascimento de um caprino transgênico na América Latina.

Palavras-chave: transgênese, caprino, hG-CSF, microinjeção de DNA, embrião.

\section{REFERENCES}

Anderson DR, Holmes WW, Lee RB, Dalal SJ, Hurst CG, Maliner BI, Newmark J and Smith WJ. 2006. Sulfur mustard-induced neutropenia: treatment with granulocyte colony-stimulating factor. Mil Med 171: 448-453.

Baldassarre H And Karatzas CN. 2004. Advanced assisted reproduction technologies (ART) in goats. Anim Reprod Sci 82-83: 255-266.

BAldassarRe H ET AL. 2003. Production of transgenic goats by pronuclear microinjection of in vitro produced zygotes derived from oocytes recovered by laparoscopy. Theriogenology 59: 831-839.

Baldassarre H, Wang B, Gauthier M, Neveu N, LAZARIS A AND KARATZAS CN. 2004. Effect of GnRH injection timing in the production of pronuclear-stage zygotes used for DNA microinjection. Zygote 12: 257-261.

Dvoryanchikov GA, Serova IA, Andreeva Le, Dias LPB, AzEVEDo S AND SEROV OL. 2005. Secretion of biologically active human granulocyte colony-stimulating factor (G-CSF) in milk of transgenic mice. Genetika 41: $1310-1318$

EBERT KM AND SCHINDLER JES. 1993. Transgenic farm animals: progress report. Theriogenology 39: 121-135.

Ebert KM, Selgrath JP, Ditullio P, Denman J, Smith Te, Memon MA, Schindler JE, MonasterSKY GM, Vitale JA AND Gordon K. 1991. Transgenic production of a variant of human tissue-type plasminogen activator in goat milk: generation of transgenic goats and analysis of expression. Biotechnology 9: 835838 .

FREITAS VJF, BARIL G AND SAUMANDE J. 1997. Estrus synchronization in dairy goats: use of fluorogestone acetate vaginal sponges or norgestomet ear implants. Anim Reprod Sci 46: 237-244.

FREITAS VJF ET AL. 2003. Birth of normal kids after microinjection of pronuclear embryos in a transgenic goat (Capra hircus) production program in Brazil. Gen Mol Res 2: 200-205.
Gootwine E, Barash I, Bor A, Dekel i, Friedler A, Heller M, Zaharoni U, Zenue A and Shani M. 1997. Factors affecting success of embryo collection and transfer in a transgenic goat program. Theriogenology 48 : 485-499.

Ko JH ET AL. 2000. Production of biologically active human granulocyte colony stimulating factor in the milk of transgenic goat. Transg Res 9: 215-222.

LeE WK, Han YM, Shin ST, Lee DH, Yoo OJ AND LeE KK. 1997. In vitro development of DNA-injected embryos co-cultured with goat oviduct epithelial cells in Korean native goats (Capra hircus aegagrus). Theriogenology 47: 1115-1123.

LEE CS ET AL. 2000. Embryo recovery and transfer for the production of transgenic goats from Korean native strain, Capra hircus aegragrus. Small Rum Res 37: 57-63.

LU CZ AND XIAO BG. 2006. G-CSF and neuroprotection: a therapeutic perspective in cerebral ischaemia. Biochem Soc Trans 34: 1327-1333.

Morstyn G AND Burgess AW. 1988. Hemopoietic growth factors: A review. Cancer Res 48: 5624-5637.

OH J, KIM DH AND KANG H. 2006. Granulocyte colonystimulating factor and acute myocardial infarction. JAMA 296: 1968-1969.

Pope WF, Cardenas H, Wiley TM and McClure Ke. 1995. Dose-response relationships of exogenous progesterone shortly after ovulation on estrous cycle length, blastocyst development and fertility in sheep. Anim Reprod Sci 38: 109-117.

Ramunno L, Consenza G, Rando A, Illario R, Gallo D, Di Berardino D and Masina P. 2004. The goat s1-casein gene: gene structure and promoter analysis. Gene 334: 105-111.

SAmbrook J, Fritsch EF And Maniatis T. 1989. Molecular Cloning: A Laboratory Manual. Cold Spring Harbor, New York: Cold Spring Harbor Lab. 1989.

SOUZA LM ET AL. 1986. Recombinant human granulocyte colony-stimulating factor: Effects on normal and leukemic myeloid cells. Science 232: 61-65.

Viret F, Goncalves A, TARPin C, Chabannon C AND VIENS P. 2006. G-CSF in oncology Bull Cancer 93: 463471.

WANG B ET AL. 2002. Transgenic goats produced by DNA pronuclear microinjection of in vitro derived zygotes. Mol Reprod Dev 63: 437-443. 
This article has received corrections in agreement with the ERRATUM published in Volume 80 Number 1. 